\title{
Facebook and a Fair Trial: Caution, Challenge and Contradiction
}

\author{
Kate Tubridy \\ University of Wollongong, Australia
}

\begin{abstract}
This article explores the often fraught intersections between social media, fair trial principles and community engagement with high-profile crimes. Specifically, a detailed analysis is undertaken of the Facebook response to the arrest of Adrian Ernest Bayley for the murder of Ms Gillian (Jill) Meagher in Victoria, Australia in 2012. As one of the first Australian crimes to receive a significant social media response, this research provides empirical insights into the dynamic and evolving relationship between social media, the community and criminal trials. By drawing on a critical discourse analysis of over 3,000 comments on the R.I.P Jill Meagher Facebook page, this article identifies and critiques a 'Discourse of Challenge' in which digital communication enabled the reinterpretation of legal principles. Further, this article provides empirical insights into the meaning-making processes of Facebook discourses and focuses on how fair trial principles are contested on Facebook in novel and, at times, contradictory, ways.
\end{abstract}

Keywords: Social media; Facebook; fair trial; crime.

\section{Introduction}

Digital technologies such as social media, ${ }^{1}$ and social network sites in particular, ${ }^{2}$ have arguably become an integral part of our social, cultural and political lives. The defining features of social network sites, including their interactivity and user-generated content, offer dynamic opportunities for the community to engage with a range of public issues, including criminal justice matters. ${ }^{3}$ User-generated content refers to how 'users employ the platform for generating content that they upload'. ${ }^{4}$ As the Chief Justice of the New South Wales Supreme Court, Thomas Bathurst AC observed, '[w]ith social media, content is not merely consumed by users, it is also created, organised and distributed by them' ${ }^{5}$ This means that social media has arguably 'pulverised' and 'erased' the previous divide between the media as the producer and the citizen as the user/consumer. ${ }^{6}$ This is significant because it suggests a shift in power in the production of information and meanings. Notably, Former Chief Justice of Canada Beverley McLachlin PC stated that:

\footnotetext{
${ }^{1}$ Keyzer et al. define social media as 'a collective term for a group of internet-based applications that allow users to create, organise and distribute messages, pictures and audio-visual content': Keyzer, "The Courts and Social Media," 47.

${ }^{2}$ Ellison, "Sociality through Social Network Sites," 158 in which social network site is defined as: ... a networked communication platform in which participants 1) have uniquely identifiable profiles that consist of user-supplied content, content provided by other users, and/or system-provided data; 2) can publicly articulate connections that can be viewed and traversed by others; and 3) can consume, produce, and/or interact with streams of user-generated content provided by their connections on the site.

${ }^{3}$ Extensive research has been conducted on the diverse participatory capacity of social media across a range of public issues. See the author's previous discussion of this in Tubridy, "So the Justice System was to Blame yet Again," 384.

${ }^{4}$ Fuchs, Social Media, 110.

${ }^{5}$ The Hon T Bathurst quoted in Johnston, "Juries and Social Media," 2.

${ }^{6}$ Gies, "Law and the Media," 15.
}

This work is licensed under a Creative Commons Attribution 4.0 International Licence. As an open access journal, articles are free to use with proper attribution. ISSN: 2652-4074 (Online) 
Newspapers, radio and television, despite their importance, are now old technology. Many people today-the young and even the not so young - use social media as their main sources of information. Without exaggeration, we are witnessing a profound cultural shift in how people communicate and how information is packaged, disseminated and consumed. ${ }^{7}$

In the criminal justice space, the erosion of this divide has widened opportunities for the community to participate in, and interpret, criminal justice processes. Particularly in high-profile criminal matters, social media can therefore provide a space for community members to voice their views on the accused, criminal justice institutions and legal principles more broadly. Given the remarkable growth of social network sites, particularly Facebook, this is an evolving and complex issue. In October 2012, Facebook announced it had reached 1 billion monthly active users. ${ }^{8}$ This figure has continued to grow, such that today, Facebook still has the highest number of monthly active users (now 2.41 billion) worldwide. ${ }^{9}$ In addition, 1.62 billion users worldwide visit Facebook on a daily basis..$^{10}$ These figures reveal the sheer presence and ubiquitous nature of Facebook, the leading social network site worldwide. This article focuses on the Facebook response to the arrest of Adrian Ernest Bayley for the murder of Ms Gillian (Jill) Meagher. Milivojevic and McGovern observed:

Increased concerns across Australia and international communities, including from law enforcement, regarding the potential negative impacts of social media on ongoing criminal justice investigations and the right to a fair trial were intimately played out in the Meagher case through social media engagement. ${ }^{11}$

This article will consider, in detail, how those concerns about the fair trial were indeed 'intimately played out' on the Facebook page R.I.P Jill Meagher by drawing on critical discourse analysis (CDA) ${ }^{12}$. Due to the significant social media response to this crime, this case intersected with criminal justice principles, institutions and processes at numerous levels. The analysis in this article continues the author's previous research on how understandings of criminal justice institutions and criminal punishment are constructed and circulated on Facebook. As the author's previous research has shown, the linguistic, interactive patterns in the posts that appeared on the R.I.P Jill Meagher Facebook page realised two classic 'law and order' discourses that reflected and sustained broader penal populist social practices: 1) a Discourse of Betrayal; and 2) a Discourse of Retribution. ${ }^{13}$ This research extends the author's previous research by applying the same methodology, now woven together with legal doctrinal analysis, to identify and critique a third discourse identified on the R.I.P Jill Meagher Facebook page ${ }^{14}$ : the Discourse of Challenge. In this discourse, those posting comments on the Facebook page challenged each other, challenged the administrators of the page, challenged the criminal justice system and, in their reinterpretations of legal principles, also challenged fair trial principles.

This article begins with a discussion of Australian fair trial principles and the potential issues raised by evolving technology, such as social media. Next, the case study and the methodological approach adopted for this research are outlined. Following this, some of the key findings of the analysis are highlighted. Finally, these findings are contextualised in relation to the government's response to this case. However, it should be noted that while this article examines an Australian case study and thus considers Australian legal principles, the findings are relevant to an international audience given Facebook's significant presence around the world.

\section{A Fair Trial and Facebook}

Burd and Horan posed the following question: 'In an era of digital communication, the question must be asked: can, and if so how, should the right to a fair trial be maintained in high profile criminal matters? ${ }^{15}$ It should be noted that the problems raised by the publicity surrounding high-profile crimes are not new; however, the increasing presence and user-generated nature of social media is creating novel challenges both nationally and internationally. In Australia, the High Court has recognised that

\footnotetext{
${ }^{7}$ McLachlin, "The Relationship between the Courts and the News Media," 33.

${ }^{8}$ Kiss, "Facebook Hits 1 Billion Users a Month."

${ }^{9}$ Statistica, Most Famous Social Network Sites Worldwide.

${ }^{10}$ Mohsin, "10 Facebook Stats Every Marketer Should Know."

${ }^{11}$ Milivojevic, "The Death of Jill Meagher," 30.

12 The research described in this article is part of a larger Doctor of Philosophy project. The analysis in this article explains the key findings in relation to one of the discourses that is being researched in that project. See the author's previous research: Tubridy, "So the Justice System was to Blame yet Again."

${ }^{13}$ Tubridy, "So the Justice System was to Blame yet Again."

${ }^{14}$ R.I.P Jill Meagher Facebook page, https://www.facebook.com/jillmeaghertribute/

15 Burd, "Protecting the Right to a Fair Trial in the 21 st Century," 103.
} 
the fair trial principle is the 'central thesis of the administration of criminal justice'. ${ }^{16}$ Australian courts have been reluctant to conclusively, and exhaustively, define the features of a fair trial; ${ }^{17}$ however, the general attributes of a fair trial have been identified in international covenants. Notably, Article 14 of the International Covenant on Civil and Political Rights (ICCPR) ${ }^{18}$ lists a number of minimum guarantees to ensure a fair trial, including:

14(1): All persons shall be equal before the courts and tribunals. In the determination of any criminal charge against him, or of his rights and obligations in a suit at law, everyone shall be entitled to a fair and public hearing by a competent, independent and impartial tribunal established by law.

14(2): Everyone charged with a criminal offence shall have the right to be presumed innocent until proved guilty according to law. ${ }^{19}$

In Dietrich v The Queen ${ }^{20}$, Brennan J noted that while the ICCPR 'is not part of our municipal law, it is a legitimate influence on the development of the common law'. ${ }^{21}$ Despite the reluctance of the High Court of Australia to exhaustively list all attributes of 'fairness', it is well recognised that 'at its core, the right to a fair trial requires that the jury decide the case solely on the evidence presented in court'. ${ }^{22}$ This is clearly acknowledged in Article 14(1) of the ICCPR, which requires an 'independent and impartial tribunal'.

This raises the difficulty of how to ensure first, that jurors only decide a case on the admissible evidence and second, that publishers do not produce information that could prejudice a juror's decision-making in a criminal trial. As 'impartial triers of fact', jurors need to be protected from 'potentially prejudicial information relevant to the trial that has not been tested by the parties'. ${ }^{23}$ At common law, prejudicial material has been 'defined as material published that creates a real or substantial risk of prejudicing the conduct of a fair trial and would generally be inadmissible in judicial proceedings' ${ }^{24}$ In Dupas v The Queen, ${ }^{25}$ the High Court confirmed the Australian common law position that judicial directions are effective in shielding the jury from prejudicial information. In addition, the laws of sub judice contempt prohibit the publication of prejudicial information once a criminal matter is sub judice. ${ }^{26}$ A criminal matter generally becomes sub judice once a person has been arrested or charged. ${ }^{27}$ The law of sub judice contempt seeks to deter and punish those who publish prejudicial material, while suppression and nonpublication orders have traditionally been used to prevent or restrain publication. ${ }^{28}$ For example, general suppression orders suppress material that has 'a tendency to interfere with the fairness of the anticipated trial'. ${ }^{29}$

The former Chief Justice of the Supreme Court of New South Wales, the Hon James Spigelman AC, suggested that the 'internet poses a challenge to the ability to ensure that a fair trial has occurred and renders less efficacious some of the mechanisms hitherto adopted to insulate the tribunal of fact' ${ }^{30}$ Similarly Johnston argued that:

\footnotetext{
${ }^{16}$ McKinney $v$ The Queen (1991) 171 CLR 468 at 478.

${ }^{17}$ In Dietrich v The Queen (1992) 77 CLR 292 in which Mason CJ and McHugh J stated at 300: '[T] here has been no judicial attempt to list exhaustively the attributes of a fair trial.'

${ }^{18}$ See also Council of Europe 1988, Art 6.

${ }^{19}$ It should also be noted that the Charter of Human Rights and Responsibilities Act 2006 (Vic) (the Charter) expressly incorporates the ICCPR fair trial provisions in sections 24 and 25. Bagaric, Faris and Alexander noted that the Charter does not create 'legally enforceable rights and duties': Bagaric, Australian Human Rights Law, 33. Given that the case study considered in this article was in Victoria, it is important to acknowledge sections 24 and 25 of the Charter. However, the insights this article draws from the case study apply more broadly to other jurisdictions. Additionally, Bagaric, Faris and Alexander recognise that sections 24 and 25 'map closely' the elements of a fair trial from Australian common law: Bagaric, Australian Human Rights Law, 308. Thus, this article focuses on setting out the Australian common law fair trial principles more broadly.

${ }^{20}$ Dietrich v The Queen (1992) 77 CLR 292.

${ }^{21}$ Dietrich v The Queen (1992) 77 CLR 292 at 321.

22 Burd, "Protecting the Right to a Fair Trial in the 21 st Century," 104.

${ }^{23}$ Horan, Juries in the 21 st Century, 150.

${ }^{24}$ Holland, "Judicial Instructions," 88.

${ }^{25}$ Dupas $v$ The Queen (2010) 241 CLR 237

${ }^{26}$ See New South Wales Law Reform Commission. Contempt by Publication Discussion Paper No. 43, 2000.

27 James v Robinson (1963) 109 CLR 593. See also Butler, Australian Media Law, 379.

${ }^{28}$ For a detailed discussion of suppression orders and non-publication orders see News Digital Media Pty Ltd v Mokbel (2010) 30 VR 248.

${ }^{29}$ Fairfax Digital Australia \& New Zealand Pty Ltd v Ibrahim (2012) 293 ALR 384

${ }^{30}$ Spigelman, "The Internet and the Right to a Fair Trial," 331.
} 
[S]ocial media have colonised the courts just as they have government, the corporate sector and the broader communications landscape, presenting a radical shake up to all organisational communication and a heightened visibility that is neither simply contained nor easily controlled. ${ }^{31}$

This article is particularly important given that posts to social media platforms can remain visible for lengthy periods. ${ }^{32}$ Further, despite the current reliance on the effectiveness of judicial directions to a jury, ${ }^{33}$ 'research suggests that jurors are in fact affected by publicity even when they believe (and tell the court) that they are not'. ${ }^{34}$

This research is set against the current debate as to whether mechanisms, such as sub judice contempt and suppression orders, are effective in an evolving digital environment. ${ }^{35}$ Arguably, sub judice contempt and suppression orders may be 'effective in controlling prejudicial media coverage in the traditional media (newspaper, radio and television)'; however, 'the laws do not translate well to information published online by independent publishers' ${ }^{36}$ Most recently, Hews and Suzor analysed Twitter comments posted during the high-profile trial of Gerard Baden-Clay and concluded that while the existing regulation of mainstream media was 'somewhat effective', it was 'much less successful' at influencing social media users. ${ }^{37}$ Research has been conducted on the effectiveness of the current reliance on judicial directions to negate online prejudicial publicity given the 'integral' ${ }^{38}$ and 'instinctive ${ }^{39}$ nature of social media for jurors. There is also research on the potential options for legal reform in this area ${ }^{40}$ Notably, at the time at which this article was being written, a number of ongoing Australian government law reform projects examining these complex issues were also being conducted. ${ }^{41}$ The analysis undertaken in this article provides new insights into how a social network site, such as Facebook, may intersect with fair trial principles. Rather than taking a purely doctrinal approach, this article draws on CDA to shed light on the chaotic meaning-making processes that follow a high-profile arrest. The next section explains some key aspects of the case study.

\section{The Facebook Response to the Arrest of Adrian Ernest Bayley}

On 27 September 2012, Victorian Police arrested Adrian Ernest Bayley for the murder of Ms Meagher, who had gone missing in the early hours of Saturday, 22 September 2012 while walking home in Melbourne, Victoria. Following her disappearance, a Facebook page entitled Help us Find Jill Meagher was created on Sunday 23 September 2012 at 12.30 pm. ${ }^{42}$ Within 4 days, the Facebook page had gained over 90,000 followers. ${ }^{43}$ On 26 September 2012, the Victorian Police released closed-circuit television (CCTV) footage from the night Ms Meagher went missing, which showed a man speaking to Ms Meagher. ${ }^{44}$ The CCTV footage was circulated widely across Facebook and Twitter. ${ }^{45}$ On 27 September 2012, Victorian Police arrested the man seen in the CCTV footage, Adrian Ernest Bayley, who took the police to the location at which he had buried Ms Meagher. Following Bayley's arrest, a Facebook page entitled R.I.P Jill Meagher was created on 27 September 2012. The morning after Bayley's arrest, The Age reported that Ms Meagher was mentioned on Twitter or Facebook every 11 seconds and appeared in

\footnotetext{
${ }^{31}$ Johnston, "Courts' New Visibility 2.0," 53.

${ }^{32}$ Thus, delay between publication and trial may no longer be effective. See Spigelman, "The Internet and the Right to a Fair Trial," 336 , and Burd, "Protecting the Right to a Fair Trial in the 21st Century," 113-114.

${ }^{33}$ Dupas $v$ The Queen (2010) 241 CLR 237; Hughes v R [2015] NSWCCA 330

${ }^{34}$ Horan, Juries in the $21^{\text {st }}$ Century, 188.

${ }^{35}$ See for example Braun, "Yesterday is History, Tomorrow is a Mystery"; Hews, "Scum of the Earth"; Buckley, "Pre-trial Publicity, Social Media and the Fair Trial"; Keyzer, "The Courts and Social Media"; Burd, "Protecting the Right to a Fair Trial in the $21^{\text {st }}$ Century."

${ }^{36}$ Horan, Juries in the 21 st Century, 177.

${ }^{37}$ Hews, "Scum of the Earth," 1631.

${ }^{38}$ Keyzer, "The Courts and Social Media," 37

${ }^{39}$ Horan, Juries in the 21 st Century, 5.

${ }^{40}$ For example, McEwan, Eldridge and Caruso recently examined the move towards judge-alone trials and argued that it is dangerous to assume that 'trial by judge-alone is an adequate response to the risks posed by prejudicial publicity.' McEwan, "Differential or Deferential to Media?" 140.

${ }^{41}$ For example, NSW and Victoria have initiated law reform reviews in this area. The NSW Law Reform Commission is currently conducting a review on "Court and Tribunal Information: Access, Disclosure and Publication." On 16 May 2019, the Victorian Law Reform Commission published a consultation paper, seeking input into its review of the law of contempt of court. The consultation paper included discussion on social media. See: Victorian Law Reform Commission. "Contempt of Court."

${ }^{42}$ Milivojevic, "The Death of Jill Meagher," 23.

${ }^{43}$ Milivojevic, "The Death of Jill Meagher," 23.

${ }^{44}$ Milivojevic, "The Death of Jill Meagher," 23.

${ }^{45}$ Ainsworth, "Worldwide Outpouring of Grief"; Lowe, "Trial by Social Media Worry in Meagher Case." There were also Facebook 'hate' pages set up directed at the accused, including 'Publicly Hang Adrian Ernest Bailey.' These 'hate' pages were shut down by Facebook after repeated requests for their removal from the Victorian Police; see: Wells, "Facebook Refuses Request to Drop Meagher Page."
} 
more than 35 million Twitter feeds. ${ }^{46}$ It should be noted that the analysis presented in this research focuses on the posts on the R.I.P Jill Meagher Facebook page, which was created following Bayley's arrest. ${ }^{47}$

Powell, Overington and Hamilton suggest that the social media response to this crime 'stands out as one of the first crime events with such a large Australian uptake via social media'. ${ }^{48}$ On 10 October 2012, Bayley's defence counsel applied for a suppression order after tendering social media material that counsel reportedly argued was 'designed to express hatred or incite hatred' in relation to Bayley. ${ }^{49}$ On 11 October 2012, Deputy Chief Magistrate Felicity Broughton granted an order prohibiting the publication of Bayley's background but did not grant an order in relation to publications of Bayley's image. Deputy Chief Magistrate Broughton noted that the 'mainstream media had not published any material in the order sought by the defence, but the area of threat or concern principally lay with "non-mainstream" media'. ${ }^{50}$ At Bayley's committal hearing on 12 March 2013, the Melbourne Magistrates' Court made an order ${ }^{51}$ prohibiting the publication of any information concerning Bayley's previous convictions. ${ }^{52}$

As Posetti stated, this case 'perfectly highlights the enormous power and potential of social media-and also the great risks' that online community support could be 'the undoing potentially of a prosecution'. ${ }^{53}$ Similarly, after Bayley's arrest, Milivojevic and McGovern observed that the 'role of Facebook' was 'at the epicentre of public attention'. ${ }^{54}$ Despite being at the 'epicentre' of discussions on the impact of social media on criminal trials, on 5 April 2013 Bayley entered a plea of guilty in the Supreme Court of Victoria before Nettle JA. ${ }^{55}$ This case did not proceed to jury trial; however, given that this was the first Australian case with such a large social media response, ${ }^{56}$ there is significant merit in analysing the Facebook comments following Bayley's arrest to gain wider insights into social media responses to high-profile crimes.

It should be noted that the comments being analysed in this article on the R.I.P Jill Meagher Facebook page were posted after Bayley's arrest but before he had pleaded guilty (i.e., during the sub judice period). This is significant, as Australian courts have recognised that during this period, an accused still has the right to the presumption of innocence and the entitlement to a trial by jury. As Bleby $\mathbf{J}$ stated in $D P P(S A)$ v Francis,${ }^{57}$ after reviewing the Australian authorities:

It is no answer to say that the accused ultimately pleaded guilty to the charge and was dealt with by a magistrate or by a judge and not by a jury. At the time of the broadcast, the accused enjoyed the presumption of innocence and the entitlement to a trial by jury. Not only were potential jurors being corrupted against him, but the broadcast had the potential to dissuade the accused himself from exercising his right to trial by jury for that very reason. ${ }^{58}$

However, this article does not seek to determine whether the comments on the R.I.P Jill Meagher Facebook page would have constituted sub judice contempt. Indeed, as Hews and Suzor acknowledged in their study of Twitter comments during the Baden-Clay trial, it is 'ultimately for the courts to establish objectively whether a particular publication is contemptuous'. ${ }^{9}$ Rather, and most importantly, this article is interested in exploring the meaning-making potential of social media within the context of the fair trial.

Due to the significant social media response to this crime, it has been the subject of previous research. Notably, Milivojevic and McGovern focused on the relationship between traditional media and social media by analysing the impact of Facebook

\footnotetext{
${ }^{46}$ Lowe, "Trial by Social Media Worry in Meagher Case."

${ }^{47}$ On 7 October 2012, it was reported that more 'than 320,000 people have joined Ms Meagher's Facebook tribute page, in one sign of the depth of public feeling.' Lillebuen, "Jill Meagher Unites a Nation in Grief."

48 Powell, "Following \#JillMeagher," 410.

${ }^{49}$ Anderson, "Web Gag."

${ }^{50}$ Anderson, "Web Gag."

${ }^{51}$ Pursuant to s126 of the Magistrates Court Act 1989 (Vic)

52 The order also prohibited publication of the pending first proceedings and any material that would identify the address or telephone number of a witness. See The Queen v Hinch [2013] VSC 520.

${ }^{53}$ Posetti quoted in Lowe, "Trial by Social Media Worry in Meagher Case."

${ }^{54}$ Milivojevic, "The Death of Jill Meagher," 30.

${ }^{55}$ See The Queen v Bayley [2013] VSC 313

56 Powell, "Following \#JillMeagher," 410.

${ }^{57}$ Director of Public Prosecutions v Francis \& Anor [2006] SASC 211

${ }^{58}$ Director of Public Prosecutions v Francis \& Anor [2006] SASC 211

${ }^{59}$ Hews, "Scum of the Earth," 1619.
} 
on the agenda-setting process of traditional media crime and justice narratives following Ms Meagher's disappearance through content analysis. ${ }^{60}$ While Powell, Overington and Hamilton considered the collective practices of meaning-making and, in particular, the representations of sexual assault and gendered issues, in Twitter responses to the murder of Ms Meagher through narrative criminology. ${ }^{61}$ This article adds a new perspective to the case study, by drawing on critical discourse analysis and legal doctrinal analysis, to provide insight into the exchange of meanings on fair trial principles. Powell, Overington and Hamilton suggested that:

Rather than taking for granted that social media content represents either a reflection of public opinion, the sharing of information or factual news reporting on crime events, we instead position social media as enabling new techno-social practices of collective narration and meaning-making in response to crime events. ${ }^{62}$

In its analysis, this article focuses on one part of these new techno-social practices of meaning-making in response to crime: the resistance to, and reinterpretation of, fair trial principles. It should be noted that the analysis in this article is mindful of the victim of this crime and does not wish to be disrespectful to Ms Meagher in any way. In drawing on this case study, the article aims to empirically examine the exchange of meanings about fair trial principles in response to this crime on Facebook. The next section describes the methodological approach that was adopted to identify and analyse these meanings.

\section{Methodological Approach}

To analyse this meaning-making potential, this article drew on the CDA approach of Fairclough (known as the dialectalrelational approach). Fairclough has suggested that the 'social effect of texts depend upon processes of meaning-making' ${ }^{63}$ Fairclough views discourses as 'ways of representing aspects of the world' ${ }^{64}$ and a 'form of "social practice", such that 'discourse is socially constitutive as well as socially conditioned' ${ }^{65}$ This research adopted Fairclough's established CDA threedimensional model to systematically analyse Facebook posts at the micro-level and gain insights into broader issues on public engagement with criminal justice matters via Facebook. In describing this method, Fairclough stated:

The method of discourse analysis includes linguistic description of the language text, interpretation of the relationship between the productive and interpretative discursive processes and the text, and explanation of the relationship between the discursive processes and social processes' ${ }^{66}$

It is well established that Fairclough's CDA approach to textual analysis, at the description level, is underpinned by the systemic functional linguistics (SFL) of Halliday. ${ }^{67}$ At the heart of SFL is the theoretical assumption that texts are the product of choices from a grammatical system network. As Halliday and Mathieson explained, 'language is a resource for making meaning and meaning resides in systemic patterns of choice'. ${ }^{68}$ The analysis in this article drew on Halliday's linguistics to identify systemic grammatical and lexical patterns at the description level. At the description level, the analysis identified linguistic patterns, including the use of pronouns, grammatical mood, rhetorical devices and verb choices (transitivity). At the next level of interpretation, the analysis drew together these linguistic patterns to identify how they 'can be seen as realising a discourse'. ${ }^{6}$ At the final macrolevel of explanation, the analysis contextualised the relationship between the discourse and broader social practices.

Fairclough identified that while there are stages in a CDA methodology, these should not be interpreted in a mechanical manner. ${ }^{70}$ The research in this article oscillated between these three levels of analysis and shows that Fairclough's methodological approach provides rich findings in the socio-technological landscape. Indeed, Fairclough's CDA approach has

\footnotetext{
${ }^{60}$ Milivojevic, "The Death of Jill Meagher."

${ }^{61}$ Powell, "Following \#JillMeagher."

62 Powell, "Following \#JillMeagher," 411.

${ }^{63}$ Fairclough, Analysing Discourse, 11.

${ }^{64}$ Fairclough, Analysing Discourse, 124.

${ }^{65}$ Wodak, Methods of Critical Discourse Studies, 6.

${ }^{66}$ Fairclough, Critical Discourse Analysis, 97.

${ }^{67}$ Janks, "Language and the Design of Texts."

${ }^{68}$ Halliday, Introduction to Functional Grammar, 23

${ }^{69}$ Fairclough, Analysing Discourse, 129.

${ }^{70}$ Fairclough in Wodak, Methods of Critical Discourse Studies, 91: 'We can identify "steps" or "stages" in the methodology only on condition that these are not interpreted in a mechanical way ....'
} 
been adopted in several recent studies analysing social media. ${ }^{71}$ However, there is still a 'strong tendency' for CDA scholars 'to focus on powerful, top-down texts and discourses of symbolic elites e.g. mass media'. ${ }^{72}$ KhosraviNik and Zia urged CDA researchers to turn their gaze to social media given that:

The linear, one-sided, one-to-many flow of texts in traditional media is now replaced by what seems to be an interactive, participatory, many-to-many flow of texts, which in turn undermines (at least at the local level) the assumed power behind the discourses of mass media. ${ }^{73}$

As discussed above, social network sites have potentially challenged the previously understood producer/user divide. This article employs Bruns' suggested term of 'produser' (producers-users) to describe those who contributed comments on Facebook. ${ }^{74}$ The term 'produser' captures the dual potential of contributors to be both users and producers of content on social media and the 'collaborative and continuous building and extending of existing content' ${ }^{75}$

However it is also important not to simplify, nor overstate, the nature of social media. As Baym and boyd recognised, it is 'popular, yet too easy, to claim that everything is different in a world of Facebook and Twitter' ${ }^{76}$ A number of scholars have argued that social media platforms 'are not neutral tools' ${ }^{77}$ In questioning this neutrality, researchers have queried the profitable nature of social media, ${ }^{78}$ the ability of platforms, such as Facebook, to influence discussions ${ }^{79}$ and the varying degrees of internet access. ${ }^{80}$ Rather, Baym and boyd argued that what needs to be considered is how social media platforms 'mirror, magnify, and complicate countless aspects of everyday life, bringing into question practices that are presumed stable and shedding light on contested social phenomena'. ${ }^{81}$ By drawing on Fairclough's CDA approach, this research was able to analyse how the techno-social practices on the R.I.P Jill Meagher Facebook page 'mirror, magnify and complicate' fair trial principles.

However, any analysis of online text as discourse is not a straightforward process. Indeed, complex ethical issues arise in relation to both publicness and traceability. Henderson, Johnson and Auld have argued that these issues 'resist simple solutions'. ${ }^{82}$ In the present article, the comments quoted were sourced from a 'community' Facebook site that is publicly available. The posts comment on a public issue in the mainstream news. The researcher did not follow or 'like' the Facebook page. This article takes the position that the data on this particular Facebook page is public but acknowledges that issues of traceability remain. Consequently, an approach similar to that of Criverallo et al. was adopted and the authors of any of the comments quoted from the Facebook page were given pseudonyms. ${ }^{83}$

The analysis of social media platforms raises many challenges for researchers; however, these platforms also provide rich data for analysis. As Stratton, Powell and Cameron noted, while the contradictory features of social media need to be acknowledged, the 'democratising potential of online participation to open up debates about crime and justice' is an 'exciting prospect' to

\footnotetext{
${ }^{71}$ See Rambe, "Critical Discourse Analysis"; Kelsey, "Discipline and Resistance on Social Media"; Criverallo, "A Pool of Dreams."

${ }^{72}$ KhosraviNik, "Persian Nationalism," 756.

${ }^{73}$ KhosraviNik, "Persian Nationalism," 756.

${ }^{74}$ Bruns, "Towards Produsage."

75 Bruns, "Towards Produsage," 276.

${ }^{76}$ Baym, "Socially Mediated Publicness," 320.

77 Poell, "Social Media," 717.

${ }^{78}$ As Langlois et al. stated: 'Major commercial Web 2.0 sites thus present us with a paradox ... On the one hand, such popular platforms allow users to express themselves to new audiences in ways that were not possible before. On the other hand, even though they are freely accessible and have come to act as seemingly quasi-public spaces, such platforms are designed to produce profits, mostly through the tracking of user behaviors, interests, and patterns of use to create new forms of customized advertising': Langlois, "FCJ-095: Mapping Commercial Web 2.0 Worlds," 2.

${ }^{79}$ van Dijck suggested that '... platforms such as Facebook are not transmitters but rather producers of sociality, enabling connections as well as forging them. Platforms are therefore socio-technical and cultural-ideological constructs that are built to create and mediate a new type of social capital: connectivity.' van Dijck, "Facebook and the Engineering of Connectivity," 141.

${ }^{80}$ Christensen stated that: '[A]part from the broader issue of the control of the Internet by large Internet service providers, Jones noted that social media, trumpeted as champions of democracy and freedom of speech, are themselves corporations that can eject users at will and restrict the kinds of groups or communicative exchanges that occur with [their] boundaries': Christensen, "Discourses of Technology and Liberation," 248-249.

${ }^{81}$ Baym, "Socially Mediated Publicness," 320.

${ }^{82}$ Henderson, "Silences of Ethical Practice," 546.

${ }^{83}$ Crivellaro, "A Pool of Dreams," 3576. In this article, produsers are identified by a number (e.g., Produser 1) and the time and date that their post was recorded. It is acknowledged that while pseudonymised posts may still be traceable, the use of pseudonymised quotations can provide a layer of protection for produsers' profiles.
} 
research and understand. ${ }^{84}$ Social media is a complex, nuanced and dynamic techno-social phenomenon that is embedded in our lives and has the potential for broader engagement in a range of public issues. As Fuchs stated:

\begin{abstract}
Media are not technologies, but techno-social systems. They have a technological level of artefacts that enable and constrain a social level of human activities that create knowledge that is produced, diffused and consumed with the help of the artefacts at the technological level. There is a recursive dynamic relation between the technological and the social level of the media. ${ }^{85}$
\end{abstract}

This article proceeds on the understanding that social networking sites, such as Facebook, are inherently embedded technosocial spaces in which we can 'contest, question and challenge matters of concern'. ${ }^{86}$ The next section highlights some of the key findings of the complex ways in which produsers on the R.I.P Jill Meagher Facebook page cautioned, challenged and contested the principles of a fair trial.

\title{
Produsers and the Principles of a Fair Trial: A Discourse of Challenge
}

In The Queen $v$ Hinch ${ }^{87}$ Kaye J discussed the concept of a fair trial and stated that the law 'does not differentiate' between 'the virtuous and the villainous':

\begin{abstract}
Each person, who is charged with a criminal offence, has an equal right to a fair trial. The same right is accorded by the law, and protected by the courts, in equal measure, to the rich and to the poor, to the strong and to the weak, and to the virtuous and to the villainous. The law does not differentiate between them. ${ }^{88}$ (emphasis added).
\end{abstract}

However, the broader research project (upon which this article drew) found that Facebook produsers both constructed, and made meaning from, such a differentiation between the 'virtuous and the villainous' in response to this crime. ${ }^{89}$ Notably, as the author has previously identified, the accused was largely referred to through the use of animal metaphors and there was an overlexicalisation of the accused as 'evil', 'scum', 'monster' and 'predator'. ${ }^{90}$ As one produser stated: '... He is a monster and evil and doesn't deserve to walk this earth ....' ${ }^{91}$ (emphasis added).

The accused in this case was therefore positioned on the R.I.P Jill Meagher page as the 'evil other', who was outside community expectations and thus deserving of violent retribution. Joffe recognised that the concept of 'the other' is well established in cultural theory and 'generally includes those outside of, and implicitly subordinate to, the dominant group' ${ }^{92}$ The author's previous research showed how many of the posts on the R.I.P Jill Meagher Facebook page demonstrated a vengeful desire for punishment. ${ }^{93}$ These textual exchanges all fed into a retributive discourse in which it was understood that the violent punishment of the accused would facilitate justice. ${ }^{94}$ The analysis in this article shows how this vengeful desire and the divisive dichotomy between the virtuous and the villainous also underpinned the often tense meaning-making process on the Facebook page about fair trial principles.

In response to this crime, produsers commented on the potential risk of social media to Bayley's trial and the principles of a fair trial more broadly. An analysis of these comments revealed an interesting multilayered 'Discourse of Challenge' of challenging each other, challenging the administrators of the page, challenging fair trial principles and challenging the criminal justice system. That is, produsers pleaded with each other to stop posting, demanded the Facebook administrator take action, reinterpreted legal principles and blamed the criminal justice system for any consequences of social media engagement with this crime. The Discourse of Challenge was marked by linguistic patterns in mood and verb choices (transitivity), as well as the use of pronouns and rhetorical devices. In particular, questions on the fair trial were exchanged between produsers through

\footnotetext{
${ }^{84}$ Stratton, "Crime and Justice in Digital Society," 30.

${ }^{85}$ Fuchs, Social Media: A Critical Introduction, 37.

${ }^{86}$ Crivellaro, "A Pool of Dreams," 3574.

${ }^{87}$ The Queen v Hinch [2013] VSC 520

${ }^{88}$ The Queen $v$ Hinch [2013] VSC 520 at 115.

${ }^{89}$ However, it should be acknowledged that this ideal of the fair trial may be compromised at various stages of the criminal justice process in practice.

90 Tubridy, "So the Justice System was to Blame yet Again," 397.

91 Produser 241, 30 September 2012 at 11.42 pm.

92 Joffe, "Risk and 'the Other,", 18.

93 Tubridy, "So the Justice System was to Blame yet Again," 398.

94 Tubridy, "So the Justice System was to Blame yet Again," 399.
} 
the use of imperative and interrogative statements. The transitivity patterns also revealed that this discourse was largely driven by an emotive desire for justice.

\section{Produsers Challenging Each Other: Cautioning and Pleading}

Many comments on the R.I.P Jill Meagher Facebook page urged other produsers to stop commenting. In these comments, the frequent use of the word 'careful' served as a plea to other produsers to be cautious in the information and comments they

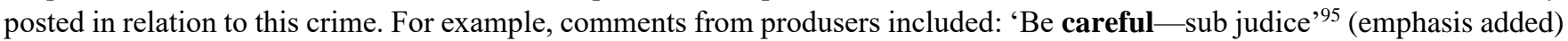
and 'Please be careful with this ...' 96 (emphasis added).

In their pleas for caution, produsers demonstrated an express awareness of the potential impact of their comments to Bayley's trial. Indeed, the first comment quoted above expressly uses legal terminology (i.e., 'sub judice') in cautioning others to be careful. Other comments demonstrated a similar awareness and used the imperative mood with the addition of the word 'please'. The use of the word 'please' before an imperative sentence constructed a sense of pleading with other produsers. Imperatives are commands; however, the addition of the word 'please' before 'don't' and the repeated use of the word 'please' in some posts created the sense that the produsers were begging one other. Other posts included:

[P]lease please please don't say anything that can stuff up THAT BASTARD getting charged with EVERYTHING that [he] can be charged with ${ }^{97}$ (emphasis added).

Please don't post anything regarding the perpetrator of this horrific crime ... It may prejudice the hope for a fair trial, \& the hope that this person spend [sic] the rest of his days behind bars. ${ }^{98}$ (emphasis added).

The use of transitivity (i.e., the selection of verb processes) demonstrates the motivation for produsers pleading with each other. Halliday identified four subtypes within the class of 'mental' clauses of transitivity. ${ }^{99}$ In the Challenge Discourse, two of these subtypes were prominent: emotive and desiderative. The produsers often moved between the 'emotive' fear or worry about a potential mistrial and the desiderative 'hope' and 'want' for punishment. By analysing the choice of verbs, the reason behind the pleas for caution were able to be identified in this case; these pleas were not made to protect the fair trial of Bayley, but to ensure that he was punished. Thus, it was actually a desire for punishment that motivated the pleas that produsers be careful in what they posted. There was also significant repetition of the words 'anger' and 'angry'. For example, the posts included:

I understand everyone's anger but this will only allow him to get off the charges, due to unfair trial. ... Please everyone be mindful of this ${ }^{100}$ (emphasis added).

Everyone is angry about what happened but we need to be aware that we could interfere with the justice system if we put up to [sic] much information about this man ... ${ }^{101}$ (emphasis added).

In such posts, produsers appeared to feed off each other's emotions, repeating similar phrases about 'anger' and pleading with 'everyone' to be 'careful'. However, in the interactive and user-generated space of Facebook, this also enabled temporal exchanges to occur between produsers in quick succession. The produsers challenged each other as they directly argued over the risk of social media potentially undermining Bayley's trial. For example, one produser stated: ‘... keep in mind your comments for her she deserves the trial he requires! Don't throw the trial through your emotions'. ${ }^{102}$ Some two minutes later, the following comment was posted: 'No I disagree we all should be heard'103 (emphasis added).

Later, a number of comments were posted that demonstrated a similar tension between produsers. The produsers argued with each other about commenting on the crime and any potential impact on the trial of Bayley. This is particularly evident in two

\footnotetext{
95 Produser 230, 28 September 2012 at 5:42 pm.

96 Produser 232, 28 September 2012 at 6:33 pm.

${ }^{97}$ Produser 201, 28 September 2012 at $9.02 \mathrm{pm}$.

98 Produser 220, 30 September 2012 at $4.52 \mathrm{pm}$.

${ }^{99}$ Halliday, An Introduction to Functional Grammar, 256.

${ }^{100}$ Produser 199, 30 September 2012 at 7.43 pm.

${ }^{101}$ Produser 234, 28 September 2012 at 6:28 pm.

102 Produser 204, 30 September 2012 at 7:45 pm.

${ }^{103}$ Produser 205, 30 September 2012 at 7:47 pm.
} 
posts. In the first post, a produser stated: 'Remember the acussed [sic] lawers [sic] will be browsing these posts. Hold your tongues till after the trial' ${ }^{104}$ (emphasis added). Some five minutes later, a comment was posted in direct response to the above comment by using the produser's name at the start of the comment (for the purposes of this article, the produser's name has been replaced with a de-identified produser number): '[Produser 206] I wouldn't worry he took the police to where he buried her'. ${ }^{105}$

The comments became more aggressive in their pleas to other produsers on the issue of a fair trial. One produser stated: 'Everybody needs to shut-up. What we all want now is justice and we need to shut-up so that can happen ... '106 (emphasis added). Some nine minutes later, another produser responded directly to this posts by using the produser's name at the start of the comment, stating: '[Produser 200] I am not going to shut up my voice ... we all know who committed this crime and how poorly the outcome would be'.107

The quick succession in which these posts appeared demonstrate the interactive nature of Facebook and capture how the produsers argued back and forth with each other. These comments show the, at times, frantic and emotive nature of meaningmaking on Facebook following a high-profile crime. In both the warnings and the responses challenging those warnings, there was also the repetition of the first person plural pronoun 'we'. As produsers asserted their positions on the risks to the right to a fair trial, they used the pronoun 'we' to appeal to a united Facebook community. Yet interestingly, the comments showed significant disagreement and conflict.

Despite this conflict, these posts display the lexical repetition of words related to speech (e.g., 'voice', 'tongues', 'shut-up' and 'heard'). There was a strong sense of 'voice' and being 'heard' via Facebook on this criminal justice matter. Some produsers refused to 'shut-up' and demanded to be 'heard' on Facebook. In these posts, a sense of power emerges. Machin and Mayr suggested that detailed linguistic analyses 'can allow us to reveal more precisely how speakers and authors use language and grammatical features to create meaning, to persuade people to think about events in a particular way'. ${ }^{108}$ The linguistic patterns on the R.I.P Jill Meagher Facebook page show that some produsers felt entitled and empowered via Facebook to comment on the crime. Conversely, the fair trial principle was interpreted as silencing this voice and eroding this power. This analysis suggests that community members value their voice on criminal justice matters and want to be heard on these issues.

\section{Produsers Challenging the Facebook Page Administrator: Demanding and Challenging}

In addition to challenging each other, produsers also challenged the administrator of the Facebook page to take action. In many comments, produsers spoke directly to the Facebook administrators. For example, produsers' comments included: 'THIS NEEDS TO BE DELETED!! These posts are what could cause a mistrial. Admin please delete?'109 and 'This needs to be deleted. If he pleads not guilty his lawyers have every right to use this as evidence of how he cannot get a fair trial ...'.110

The use of capitals was marked in this Discourse of Challenge and suggests that the produsers are SCREAMING at the page administrators to be heard on this issue. Interestingly, there was evidence that the page administrator did take action to remove comments. For example, as the following comment shows, the page administrator did regulate the Facebook page to some extent:

Ok. You have deleted my comment but my concern is very real. Social media is considered publication. Posting things like this does not help and could seriously impede the court process. Please familiarise yourselves with the contempt of court laws: http://www.thenewsmanual.net/Manuals.../volume3_68.htm. ${ }^{111}$

\footnotetext{
${ }^{104}$ Produser 206, 30 September 2012 at 9:15 pm.

${ }^{105}$ Produser 207, 30 September 2012 at 9:20 pm.

${ }^{106}$ Produser 200, 30 September 2012 at 10:03 pm.

${ }^{107}$ Produser 209, 30 September 2012 at 10:12 pm.

108 Machin, How to Do Discourse Analysis, 1.

${ }^{109}$ Produser 239, 29 September 2012 at 8:40 am.

${ }^{110}$ Produser 241, 30 September 2012 at $11.42 \mathrm{pm}$.

${ }^{111}$ Produser 251, 28 September 2012 at 5:51 pm.
} 
In the first sentence, the produser is expressly remarking on the removal of their previous comment. This suggests that other comments may have also been removed by the administrator of the page. ${ }^{112}$ However, it is difficult to know with any certainty how many, if any, other comments were removed. The above comment demonstrates that the page administrator was conducting their own regulation of the page, perhaps based on their own interpretations of sub judice contempt and fair trial principles. Given the derogatory comments that remained on the page, this internal regulation may not have been consistent with current Australian legal principles on prejudicial publicity; however, it does demonstrate a novel capacity for internal sociotechnological regulation outside the bounds of court ordered suppression orders.

The above comment also provides an example of an informed understanding of contempt laws as it directs others to a link to an online resource for journalists. This was not the only produser to provide links to resources. For example, another produser stated: '... Please share this article and ask your friends to shut-up' and 'University of Canberra journalism academic Julie Posetti said users needed to be aware of potential implications of "trial by social media" by posting about the accused ...'. ${ }^{113}$ Such comments show an understanding of the fair trial principles and an express awareness of the risks of social media to criminal trials. Interestingly, other comments also showed an understanding of the fair trial principle and, in doing so, demonstrated a reinterpretation of settled legal principles.

\section{Produsers Challenging Fair Trial Principles: Reinterpretations and Resistance}

This article showed that not only were produsers aware of fair trial principles, they also reinterpreted and showed resistance to those principles. In the comments posted to the R.I.P Jill Meagher Facebook page, the use of rhetorical phrases, such as 'thrown out' and 'get off', suggest that the fair trial principle was interpreted as a technical avenue for an accused to avoid conviction. Further, it was understood to be a principle that could 'throw' a trial rather than a principle that sought to protect the rights of the accused:

I want justice for Jill it but it wont [sic] help if the killer gets off because of an unfair trial ... ${ }^{114}$ (emphasis added).

Posting things like this on Facebook are only helping him, sure he's a sicko, he only deserves the worst ... but if things keep going like this his case will be thrown out because his trial won't be deemed 'fair and unbiased' ... ${ }^{115}$ (emphasis added),

There was a strong sense that the fair trial principle could undermine both what the victim and the accused 'deserved' in this case. Arguably, the fair trial principle was reinterpreted as being about punishing (rather than protecting) an accused. That is, protecting the fair trial of the accused was to ensure that their trial went ahead and they receive their punishment, which in turn, would ultimately ensure justice for the victim. As one produser stated: ' ... keep in mind your comments for her she deserves the trial he requires!' ${ }^{116}$ (emphasis added).

It should also be noted that Australian courts have to balance the right to a fair trial with the 'social imperative of bringing suspects to trial'. ${ }^{117}$ However the way in which fair trial principles were reinterpreted on the R.I.P Jill Meagher Facebook page was not directed towards this balancing act. Indeed, these reinterpretations directly connect the protection of a fair trial with ensuring punishment.

Sharp's research showed that the public has an instinctive desire for retribution whereby 'punishment equates with justice'. ${ }^{118}$ This retributive desire and the equation of punishment with justice motivated the reinterpretations of fair trial principles on the R.I.P Jill Meagher Facebook page. This is consistent with, and builds on, the author's previous research on this case study, which showed that the Facebook comments fed into a retributive discourse in which the violent punishment of the offender was understood to facilitate 'justice'. ${ }^{119}$ Chan, Goggin and Bruce found that 'produsage' allows citizens to 'act as new kinds of

\footnotetext{
${ }^{112}$ For a recent judicial consideration of the obligations of Facebook administrators, see Voller $v$ Nationwide News Pty Ltd; Voller v Fairfax Media Publications Pty Ltd; Vollerv Australian News Channel Pty Ltd [2019] NSWSC 766. However, it should be noted that this case related to a defamation claim against media companies operating Facebook pages for 'commercial ends' [at 232].

${ }^{113}$ Produser 200, 30 September 2012 at $10.03 \mathrm{pm}$.

${ }_{114}$ Produser 234, 28 September 2012 at 6:28 pm.

115 Produser 260, 28 September 2012 at 5:49 pm.

116 Produser 204, 30 September 2012 at $2.45 \mathrm{am}$.

${ }^{117}$ Bagaric, "The Illusions that is the Right to a Fair Trial," 65

${ }^{118}$ Sharp "Justice with a Vengeance," 173.

119 Tubridy, "So the Justice System was to Blame yet Again," 399.
} 
intermediaries in the process of generating information and interpretations about criminal justice'. ${ }^{120}$ The present analysis highlighted how produsage can enable and support reinterpretations of legal principles. Interspersed with these reinterpretations of legal principles were comments that challenged the criminal justice system as the institutional body responsible for providing a fair trial.

\section{Produsers Challenging the Criminal Justice System: Division and Power}

Previously, the author identified a Discourse of Betrayal on the R.I.P Jill Meagher Facebook page in which the criminal justice system was blamed for failing and, ultimately, betraying society. Similarly, in directly challenging the criminal justice system to deal with the intersection of social media and the fair trial, the criminal justice system was again positioned as failing. The produsers interpreted that any impact by social media on the criminal trial represented a failure of the criminal justice system itself, stating:

If public outrage can cause a mistrial then there is certainly something very wrong with our judicial system $!^{121}$ (emphasis added).

If he doesn't get what he deserves THIS TIME AROUND_ don't blame social media for it! ... Do not blame social media for the legal system failure ... ${ }^{122}$ (emphasis added).

As can be seen by these comments, for some produsers, the suggestion that social media could negatively impact the trial revealed a 'fault' in the 'system' rather than a fault in social media. Comments scattered across the page demonstrated a similar pattern. For example, some comments included:

[T]rial by social media is nothing to fear. the state fears. they are guilty for letting him out of jail in 93 . we will not wear their guilt. the community should not be quiet. ${ }^{123}$ (emphasis added).

I wonder how they are going to regulate social media: the experts are at it just as we post because as they insist it could affect fairness of trials ... Didn't they realise that before we started with this powerful tool that is the internet? ... Maybe they don't like the fact that we are pointing out the incompetence of some courts and the failure of the legal system. Look at that lawmakers $\ldots^{124}$ (emphasis added).

The division of 'we' and 'they' in these comments is prominent and there is a direct challenge in the final sentence to the 'lawmakers'. Machin and Mayr argued that '[p]ronouns like "us", "we" and "them" are used to align us alongside or against particular idea', which can 'create a collective other that is in opposition to these shared ideas'. ${ }^{125}$ The use of pronouns essentially supports a binary of 'us' (produsers) versus 'them' (the experts) on the risks of social media to a fair trial.

Consistent with a CDA approach, the Discourse of Challenge can be contextualised within broader social practices. Previously, the author showed how the foundational elements of a penal populist agenda were evident in and amplified by the Discourse of Betrayal. These elements were identified again in the Discourse of Challenge. Penal populism essentially explores the relationship between the public's allegedly punitive attitudes and the development of criminal justice policy. As Quilter noted, there 'has been much debate in the scholarly literature over the increasing trend in many Western countries since the 1980s towards punitive and populist penal policies and sentencing laws'. ${ }^{126}$ Pratt suggests that while there are 'common themes associated ${ }^{127}$ with penal populism, the key element is that it is 'of the people but not of the system' ${ }^{128}$ Notably, the produsers' comments above embodied 'an anti-system, anti-establishment logic' that Hogg suggests is often present in penal populism. ${ }^{129}$ The comments show a schism between 'we' (the people) and 'they' (the system). The second produser's comment shows a

\footnotetext{
${ }^{120}$ Chan, "Internet Technologies and Criminal Justice," 592.

${ }^{121}$ Produser 240, 30 September 2012 at $9.51 \mathrm{pm}$.

122 Produser 148, 2 October 2012 at 5:39 pm.

${ }^{123}$ Produser 221, 30 September 2012 at 10:23 pm.

${ }^{124}$ Produser 148, 2 October 2012 at 7:05 pm.

${ }^{125}$ Machin, How to Do Discourse Analysis, 84 .

${ }^{126}$ Quilter, "Responses to the Death of Thomas Kelly," 339.

${ }^{127}$ Pratt, Penal Populism, 92.

${ }^{128}$ Pratt, Penal Populism, 20.

${ }^{129}$ Hogg, "Punishment and 'the People,"” 112.
} 
particularly overt distrust of 'expert' opinions. The comments also demonstrate a sense of power whereby technology is used to undermine the 'expert's' power and there is pushback against the 'system's' expectation to be 'quiet'. The next section briefly highlights the response of the 'lawmakers'.

\section{The Lawmakers' Response}

While Bayley eventually pleaded guilty and so the comments on the R.I.P Jill Meagher Facebook page did not directly intersect with his trial, the comments arguably did have an impact on criminal justice institutions and policies by igniting Government action. On 1 October 2012, the Attorney-General of Victoria, Robert Clark, expressed his broader concerns, with a spokesperson for the Attorney-General informing journalists that 'he would seek urgent agreement from attorneys-general in other states to adopt a "co-ordinated, national approach" to address the challenges of social media to the legal process' ${ }^{130}$ On 5 October 2012, just one week after Bayley's arrest, the former Australian Standing Council on Law and Justice (SCLJ) (comprised of the Commonwealth, state and territory attorneys-general) released a communique of their bi-annual meeting in which they had swiftly added the agenda item of 'social media and the law'. The communique commenced with the statement that the 'Ministers noted the potential for social media to jeopardise the right to a fair trial, and in particular to compromise a jury trial and agreed to seek a coordinated national approach'. ${ }^{131}$

Following the decision in the communique, in April 2013, a report, entitled 'Juries and Social Media', was prepared for the Victorian Department of Justice. The report explored the range of problems that social media potentially raised for jury trials, including pre-trial publicity, and examined options to address these problems. ${ }^{132}$ After assessing each option, the report recommended improved jury training and support. The SCLJ communique and the subsequent report reflects the swift responsive action undertaken by the government following the social media response to this crime. Despite the Government's swift response, it was largely reactive in nature. As this article has shown, members of the community want to be heard on Facebook in relation to criminal justice issues; however, the initial response by the government desperately tried to curtail these voices. In addition, this article found that the Facebook comments were chaotic and inconsistent, demonstrating both compliance and resistance to fair trial principles and messy internal regulation. In later discussing the 'Juries and Social Media' Report, Johnston and Keyzer acknowledged that the 'challenges in dealing with this issue are complex and there is no quick fix'. ${ }^{133}$

\section{Conclusion}

The analysis undertaken in this article sheds light on the complex meaning-making processes of fair trial principles on Facebook. The research also showed that even where social media comments do not infiltrate a jury, they can affect other aspects of the criminal justice process and ignite government action. As user-generated sites, social media platforms provide highly visible forums for new voices to debate and engage with criminal justice decisions and principles. Thus, social media may now be a powerful conduit for information on and interpretations of criminal justice issues and principles.

Many of the comments posted to the Facebook page were derogatory and fuelled by hatred and vitriol towards the accused. These comments contested the protection offered under the law for a fair trial for the 'villainous'. Previously, Horan suggested that online information 'is largely unregulated' and 'jurors who conduct research risk being exposed to information that is more prejudicial than probative'. ${ }^{134}$ The analysis of this case study certainly supports Horan's points about social media comments being largely unregulated and their prejudicial, rather than probative, nature. However, the case study also demonstrates that although the comments were not effectively regulated by the traditional methods of suppression orders, there were elements of informal peer-regulation and regulation both from, and addressed to, the page administrators. As the analysis has shown though, these forms of informal regulation and resistance on the Facebook page were fraught with conflict, contradiction and inconsistencies.

\footnotetext{
${ }^{130}$ Wells, Rachel. "Facebook Refuses Request to Drop Meagher Page."

${ }^{131}$ Standing Council on Law and Justice. Communiqué, 3

132 These options included: judge-alone trials, mixed juries, delaying the start of a trial, changing trial venue, removing juror access to electronic devices and sequestering the jury.

133 Johnston, "Trial by Social Media," 2.

${ }^{134}$ Horan, Juries in the 21st Century, 175.
} 
To date, much of the research that has examined the risks of social media to the right to a fair trial has assumed that, unlike journalists, social media produsers lack an understanding of sub judice rules. ${ }^{135}$ However, the detailed analysis of the R.I.P Jill Meagher Facebook page demonstrates that many produsers were aware of prejudicial publicity and sub judice issues. The analysis revealed that far from being ignorant of sub judice laws, many produsers were not only aware of the potential legal issues, but were also willing to challenge and resist settled legal principles. As the analysis of this case study showed, there is a nuanced and often conflicting response to the potential risk of Facebook comments on the right of an accused to a fair trial. A significant number of comments showed that produsers understood the risks of prejudicial comments to Bayley's trial. These comments pleaded, warned and demanded others understand this and take appropriate action. However, as the analysis showed, these pleas for caution were driven by a desire to punish the accused rather than protect his right to a fair trial. There were also comments exhibiting an entitlement to be heard on this criminal justice matter and a push back at the criminal justice system.

Some produsers understood fair trial principles and sub judice contempt; however, the produsers were clearly focused on ensuring that prejudicial publicity did not prevent Bayley from being tried and punished. The produsers did not appear to understand or be concerned about their own potential exposure for having committed contempt. Johnston et al argued that:

This lack of appreciation of their vulnerability to a prosecution for contempt means that the law of sub judice contempt does not exert the chilling effect on their willingness to communicate about a pending case. Accordingly, there is a far greater probability that sub judice contempt will be committed via social media than via the traditional media. ${ }^{136}$

The findings of this research largely supported Johnston et al.'s argument. The motivation behind the majority of the warnings and pleadings was largely to achieve justice for the victim rather than to avoid prosecution for contempt. This is an important finding for future law reform in this area, as it shows that punitive measures, such as traditional contempt laws, may not be effective in highly emotive, justice-driven social media environments following high-profile crimes. Further, even if contempt laws are ineffective, Australian courts have largely maintained their position that juries will obey judicial instructions to ignore prejudicial material in reaching a verdict. ${ }^{137}$ Recently in Hughes $v R^{138}$, Beazley P, Schmidt and Button JJ affirmed that the jury system is 'robust' and 'capable of ensuring that a person accused of serious offences can receive a fair trial, despite prejudicial and ill intended comments widely and irresponsibly published on mainstream and social media'. ${ }^{139}$ Beazley P, Schmidt and Button JJ also stated that:

\footnotetext{
All of us, accused, victims, judges, jurors and other members of our community now live in a world of instant, largely unregulated communication of opinions disseminated by publication on social media, where they can endlessly be accessed and responded to by others ... The reality remains, however, that our civil society and the justice system which it has devised, is the means by which we help ensure that such views remain confined to social media, where those who hold such views are free to express them, rather than being acted on. ${ }^{140}$
}

Whether social media can be 'confined' by judicial directions to a jury or controlled by contempt laws remains open to debate. Importantly, as techno-social spaces, such as Facebook, continue to grow, 'social media discourse' is one way in which crime events are now 'collectively rendered meaningful'. ${ }^{141}$ However, the research findings of this article show, during an emotive period following a high-profile arrest, the meaning-making process on Facebook can be chaotic and, at times, contradictory.

\footnotetext{
${ }^{135}$ Johnston, Juries and Social Media.

136 Johnston, Juries and Social Media, 4.

${ }^{137}$ Dupas v The Queen (2010) 241 CLR 237; Hughes v R [2015] NSWCCA 330.

${ }^{138}$ Hughes $v R[2015]$ NSWCCA 330.

${ }^{139}$ Hughes $v R$ [2015] NSWCCA 330.

${ }^{140}$ Hughes $v R$ [2015] NSWCCA 330 at 68-69.

${ }^{141}$ Powell, "Following \#JillMeagher," 411.
} 


\section{Bibliography}

Ainsworth, Michelle. "Worldwide Outpouring of Grief After Man Arrested Over Jill Meagher's disappearance." Herald Sun, 28 September, 2012. https://www.heraldsun.com.au/news/victoria/worldwide-reaction-to-arrest-over-jill-meaghersdisappearance-on-social-media/newsstory/bdfea159a67f062895b3ac4a46f1e571?sv=64f7fe017ec94fe3d382f0cf843ceeb0

Anderson, Paul. "Web Gag on Hateful Adrian Bayley Material in Jill Meagher Murder Case." Herald Sun, 11 October, 2012. http://www.heraldsun.com.au/news/web-gag-on-hateful-adrian-bayley-material-in-jill-meagher-murder-case/storye6frf7jo-1226493805409

Bagaric, Mirko, Peter Faris and Theo Alexander. Australian Human Rights Law. Sydney: CCH Australia, 2011.

Bagaric, Mirko, Theo Alexander and Marlene Ebejer. "The Illusions that is the Right to a Fair Trial in Australia." Australian Journal of Human Rights 17, no 2 (2011): 59-89.

Baym, Nancy and Danah Boyd. "Socially Mediated Publicness: An Introduction." Journal of Broadcasting and Electronic Media 56, no 3 (2012): 320-329. https://doi.org/10.1080/08838151.2012.705200

Braun, Kerstin. "Yesterday is History, Tomorrow is a Mystery-The Fate of the Australian Jury System in the Age of Social Media Dependency." University of New South Wales Law Journal 40, no 4 (2017): 1634-1662.

Bruns, Axel. "Towards Produsage: Futures for User-Led Content Production." In Proceedings Cultural Attitudes towards Communication and Technology, edited by Fay Sudweeks and Herbert Hrachovec and Charles Ess, 275-284, 2006.

Buckley, Isaac. "Pre-trial Publicity, Social Media and the Fair Trial: Protecting Impartiality in the Queensland Criminal Justice System." Queensland Lawyer 33 (2013): 38-51.

Burd, Roxanne and Jacqueline Horan, "Protecting the Right to a Fair Trial in the 21st Century-Has the Trial by Jury been Caught in the World Wide Web?" Criminal Law Journal 36 (2012): 103-122.

Butler, Des and Sharon Rodrick, Australian Media Law. Sydney: Thomson Reuters, 2015.

Chan, Janet, Gerard Goggin and Jasmine Bruce, "Internet Technologies and Criminal Justice." In Handbook of Internet Crime, edited by Yvonne Jewkes and Majid Yar, 582-602. London: Routledge, 2010.

Christensen, Christian. "Discourses of Technology and Liberation: State Aid to Net Activists in an Era of Twitter Revolutions," The Communication Review 14, no 3 (2011): 233-253. https://doi.org/10.1080/10714421.2011.597263

Council of Europe. 1988. "Protocol to the Convention for the Protection of Human Rights and Fundamental Freedoms (European Convention on Human Rights) as Amended by Protocol No. 11." Council of Europe Treaty Series 155. Strasbourg: Council of Europe.

Crivellaro, Clara, Rob Comber, John Bowers, Peter C Wright and Patrick Oliver. "A Pool of Dreams: Facebook, Politics and the Emergence of a Social Movement." CHI "14: Proceedings of the SIGCHI Conference on Human Factors in Computing Systems April (2014): 3573-3582. http://dx.doi.org/10.1145/2556288.2557100.

Ellison, Nicole and Danah Boyd. "Sociality through Social Network Sites." In The Oxford Handbook of Internet Studies, edited by W H Dutton. Oxford: Oxford University Press, 2013.

Fairclough, Norman. Analysing Discourse: Textual Analysis for Social Research. Abingdon: Routledge, 2003.

Fairclough, Norman. Critical Discourse: The Critical Study of Language. London: Longman, 1995.

Fuchs, Christian. Social Media: A Critical Introduction. London: Sage, 2014.

Gies, Lieve. Law and the Media: The Future of an Uneasy Relationship. Abingdon: Routledge-Cavendish, 2008.

Halliday, M A K and Christian Mathieson. An Introduction to Functional Grammar. 4th ed. Taylor \& Francis, 2013.

Henderson, Michael, Nicola Johnson and Glenn Auld. "Silences of Ethical Practice: Dilemmas for Researchers using Social Media." Educational Research and Evaluation 19, no 6 (2013): 546-560. https://doi.org/10.1080/13803611.2013.805656

Hews, Rachel and Nicholas Suzor. "'Scum of the Earth': An Analysis: Prejudicial Twitter Conversations during the BadenClay Murder Trial." University of New South Wales Law Journal 40, no 4 (2017): 1604-1633.

Hogg, Russell. "Punishment and 'the People': Rescuing Populism from its Critics." In Crime, Justice and Social Democracy. Critical Criminological Perspectives, edited by Kerry Carrington, Michael Ball, Erin O’Brien and Juan Marcellus Tauri, 105-119. United Kingdom: Palgrave Macmillan, 2013.

Holland, Geoff. "Judicial Instructions: Do Jurors Obey Directions to Disregard Prejudicial Publicity?" In The Courts and the Media: Challenges in the Era of Digital and Social Media, edited by Patrick Keyzer, Jane Johnston and Mark Pearson, 86-100. Braddon: Halstead Press, 2012.

Horan, Jacqueline. Juries in the 21st Century. Sydney: Federation Press, 2012.

Janks, Hilary. "Language and the Design of Texts." English Teaching: Practice and Critique 4, no 3 (2005): 97-110.

Joffe, Helene. "Risk and 'the Other. "” Cambridge: Cambridge University Press, 1999.

Johnston, Jane. "Courts' New Visibility 2.0." In The Courts and the Media: Challenges in the Era of Digital and Social Media, edited by Patrick Keyzer, Jane Johnston and Mark Pearson, 41-54. Braddon: Halstead Press, 2012.

Johnston, Jane and Patrick Keyzer. "Trial by Social Media: Why We Need to Properly Educate Juries," The Conversation, 17 April, 2013. https://theconversation.com/trial-by-social-media-why-we-need-to-properly-educate-juries-13547 
Johnston, Jane, Patrick Keyzer, Geoffrey Holland, Mark Pearson, Sharon Rodrick and Anne Wallace. Juries and Social Media. (Victorian Department of Justice, 2013).

https://www.ncsc.org/ /media/Files/PDF/Information\%20and\%20Resources/juries\%20and\%20social\%20media_Australi a_A\%20Wallace.ashx

Kelsey, Darren and Lucy Bennett. "Discipline and Resistance on Social Media: Discourse, Power and Context in the Paul Chambers 'Twitter Joke Trial'.” Discourse, Context and Media 3 (2014): 37-45. https://doi.org/10.1016/j.dcm.2013.12.001

Keyzer, Patrick, Jane Johnston, Mark Pearson and Anne Wallace. "The Courts and Social Media: What do Judges and Court Workers Think?” Judicial Officers’ Bulletin 25 (2013): 47-51.

KhosraviNik, Majid and Mahrou Zia. "Persian Nationalism, Identity and Anti-Arab Sentiments in Iranian Facebook Discourses: Critical Discourse Analysis and Social Media Communication.” Journal of Language and Politics 13 (2014): 755-780. https://doi.org/10.1075/jlp.13.4.08kho

Kiss, Jemima, "Facebook Hits 1 Billion Users a Month." The Guardian, 4 October, 2012. https://www.theguardian.com/technology/2012/oct/04/facebook-hits-billion-users-a-month

Langlois, Ganaele, Fenwick McKelvey, Greg Elmer and Kenneth Werbin. "FCJ-095 Mapping Commercial Web 2.0 Worlds: Towards a New Critical Ontogenesis." The Fibreculture Journal 14 (2009). http://fourteen.fibreculturejournal.org/fcj095-mapping-commercial-web-2-0-worlds-towards-a-new-critical-ontogenesis/

Lillebuen, Steve and Genevieve Gannon. “Jill Meagher Unites a Nation in Grief.” News.com.au, 7 October, 2012. https://www.news.com.au/national/breaking-news/jill-meagher-unites-a-nation-in-grief/newsstory/d7b468fb845bef1fe46b25dd2afcb429

Lowe, A. "Trial by Social Media Worry in Meagher Case.” Sydney Morning Herald. 28 September 2012. https://www.smh.com.au/technology/trial-by-social-media-worry-in-meagher-case-20120928-26pe4.html

Machin, David and Andrea Mayr. How to Do Discourse Analysis. London: Sage, 2012.

McEwan, Rebecca, John Eldridge and David Caruso. "Differential or Deferential to Media? The Effect of Prejudicial Publicity on Judge or Jury." The International Journal of Evidence and Proof 22, no 2 (2018): 124-143. https://doi.org/10.1177\%2F1365712718765548

McLachlin, Beverley. "The Relationship between the Courts and the News Media." In The Courts and the Media: Challenges in the era of Digital and Social Media edited by Patrick Keyzer, Jane Johnston and Mark Pearson, 24-34, Braddon: Halstead Press, 2012.

Milivojevic, Sanja and Alyce McGovern. "The Death of Jill Meagher: Crime and Punishment on Social Media." International Journal for Crime, justice and Social Democracy 3, no 3 (2014): 22-39. https://doi.org/10.5204/ijcjsd.v3i3.144

Mohsin, Maryam. "10 Facebook Stats Every Marketer Should Know in 2020 [Infographic]” 3 December, 2019. https://au.oberlo.com/blog/facebook-statistics.

New South Wales Law Reform Commission. Contempt by Publication. Discussion Paper No. 43, 2000.

New South Wales Law Reform Commission. "Open Justice Review Court and Tribunal Information: Access, Disclosure and Publication." Last updated 3 June 2019.

https://www.lawreform.justice.nsw.gov.au/Pages/lrc/lrc_current_projects/Courtinformation/Project_update.aspx.

Poell, Thomas. "Social Media and the Transformation of Activist Communication: Exploring the Social Media Ecology of the 2010 Toronto G20 Protests." Information, Communication and Society 17, no 6 (2014): 716-731. https://doi.org/10.1080/1369118X.2013.812674

Powell, Anastasia, Caitlin Overington and Gemma Hamilton. "Following \#JillMeagher: Collective Meaning-Making in Response to Crime Events via Social Media" Crime Media Culture 14, no 3 (2018): 409-428. https://doi.org/10.1177\%2F1741659017721276

Pratt, John. Penal Populism. Abingdon: Routledge, 2007.

Quilter, Julia. "Responses to the Death of Thomas Kelly: Taking Populism Seriously." Current Issues in Criminal Justice 24, no 3 (2013): 439-448. https://doi.org/10.1080/10345329.2013.12035970

Rambe, Patient. "Critical Discourse Analysis of Collaborative Engagement in Facebook Postings." Australasian Journal of Educational Technology 28, no 2 (2012): 295-314. https://doi.org/10.14742/ajet.875

Sharp, Cassandra. "Justice with a Vengeance: Retributive Desire in Popular Imagination." In Law and Popular Culture: International Perspectives, edited by M Asimow and K Brown, 153-176. United Kingdom: Cambridge Scholars, 2014.

Spigelman, James J. "The Internet and the Right to a Fair Trial.” Criminal Law Journal 29, no 6 (2005): 331.

Standing Council on Law and Justice. Communiqué. 5 October 2012. https://webarchive.nla.gov.au/awa/20141215124305/http://www.lccsc.gov.au/agdbasev7wr/sclj/documents/pdf/sclj_com munique_october_2012.pdf

Statistica, Most Famous Social Network Sites Worldwide as of October 2019, Ranked by Number of Active Users (In Millions), January 2020. https://www.statista.com/statistics/272014/global-social-networks-ranked-by-number-of-users/. 
Stratton, Greg, Anastasia Powell and Robin Cameron. "Crime and Justice in Digital Society: Towards a Digital Criminology?” International Journal for Crime, Justice and Social Democracy 6, no 2 (2017): 17-33. https://doi.org/10.5204/ijcjsd.v6i2.355

Tubridy, Kate. "So the Justice System was to Blame yet Again: Discourses of Betrayal and Retribution on Facebook." Media and Arts Law Review 22 (2018): 382-402.

van Dijck, Jose. "Facebook and the Engineering of Connectivity: A Multilayered Approach to Social Media Platforms." Convergence: The International Journal of Research into New Media Technologies 19, no 2 (2013): 141-155. https://doi.org/10.1177\%2F1354856512457548

Victorian Law Reform Commission. "Contempt of Court, Judicial Proceedings Reports Act 1958 and Enforcement Processes." Last updated 3 April 2020. https://www.lawreform.vic.gov.au/all-projects/contempt

Wells, Rachel. "Facebook Refuses Request to Drop Meagher Page.” Sydney Morning Herald, 2 October, 2012. https://www.smh.com.au/technology/facebook-refuses-request-to-drop-meagher-page-20121001-26vm4.html

Wodak, Ruth and Michael Meyer (eds), Methods of Critical Discourse Studies. 3rd ed. London: Sage, 2016.

\section{Primary Legal Material}

Charter of Human Rights and Responsibilities Act 2006 (Vic)

Dietrich v The Queen (1992) 77 CLR 292

Director of Public Prosecutions v Francis \& Anor [2006] SASC 211

Dupas $v$ The Queen [2010] HCA 20

Fairfax Digital Australia \& New Zealand Pty Ltd v Ibrahim (2012) 293 ALR 384

Hughes $v$ R [2015] NSWCCA 330

James $v$ Robinson (1963) 109 CLR 593

Magistrates Court Act 1989 (Vic)

McKinney v. The Queen (1991) 171 CLR 468

News Digital Media Pty Ltd v Mokbel (2010) 30 VR 248

The Queen v Bayley [2013] VSC 313

The Queen v Hinch [2013] VSC 520

Voller v Nationwide News Pty Ltd; Vollerv Fairfax Media Publications Pty Ltd; Voller v Australian News Channel Pty Ltd [2019] NSWSC 766 